\title{
Sustainable Solid Waste Collection in Addis Ababa: the Users' Perspective
}

\author{
Mesfin Tilaye $^{1}$ and Meine Pieter van Dijk ${ }^{2^{*}}$ \\ ${ }^{1}$ Ethiopian Civil Service University, Addis Ababa, Ethiopia \\ ${ }^{2}$ Professor of urban management at ISS of Erasmus University, Netherlands
}

*Corresponding author: Meine Pieter van Dijk, Professor of urban management at ISS of Erasmus University, Netherlands, Tel: +31152151779; E-mail: mpvandijk@iss.nl

Received date: July 23, 2014; Accepted date: August 27, 2014; Published date: September 5, 2014

Copyright: () 2014 van Dijk MP, et al. This is an open-access article distributed under the terms of the Creative Commons Attribution License, which permits unrestricted use, distribution, and reproduction in any medium, provided the original author and source are credited.

\begin{abstract}
Sustainability of solid waste management is high on the agenda of urban managers. Municipalities in developing countries are incapable of meeting the demand for urban services. Some years ago Addis Ababa, the capital of Ethiopia, took the initiative to overcome some of these problems by starting a reform process. It led to a significant shift in the institutional arrangements. Community-based initiatives are becoming increasingly important as a means of addressing the deficiencies of the formal system. This paper analyzes the households' behaviour and their opinions concerning urban solid waste management practices. Sustainability will be considered from the public health, ecological and socio-economic perspective, following the PPP framework: sustainability concerns the people, the planet, and the profit sector.
\end{abstract}

Primary data consisted of a household survey and interviews of local level officials. Three types of residents were studied: those living in slums, in residential areas, and in a commercial area mixed with houses. 135 households were selected randomly in each condition. The results suggest that from a socio-economic perspective (the profit angle) the service reform suited the interests of the city community by undertaking the service provision in a more sustainable manner. Regularity, reliability, service coverage and the frequency of service delivery to the households improved. Residents also have a good feeling about cost recovery, though also differing opinions were expressed. With regard to public health (the people's angle), improvements were observed concerning the cleanliness of the neighborhoods, while the city cleanliness lagged behind. In case of ecological sustainability (the planet perspective) economic incentives played a more important role than ecological concerns in separating and collecting reusable and recyclable items from the waste stream.

Keywords: Environmental; Solid waste management (SWM); People, planet and profit; Household level

\section{Introduction}

Sustainability of cities in the developing countries has become a big question mark and has rightly been placed as the focal point of the Sustainable Development Goals, the successor of the millennium development goals. Since the Rio Summit in 1992, the concept of sustainability extends to basic services such as solid waste management (SWM). Many municipalities in developing countries are incapable of meeting the demand for services, resulting in both direct and indirect negative effects on the three dimensions of sustainable development: the people, planet and profit (PPP). This is the framework of the triple bottom line, developed by Sibley et al. [1]. Indicators include among others the area of coverage for a service, cost recovery, regular collection of refuse, dumping and burning of solid waste in open spaces or not.

About $20 \%$ to $30 \%$ of the waste generated in Addis Ababa remained uncollected and made the city environment aesthetically unpleasant and affected the city's public health. Local initiatives to create sustainable urban solid waste management play a key role. The sustainable urban development programme was initiated by the municipality of Addis Ababa as part of an urban governance strategy in 2004. The strategy was developed to meet the growing need for rendering this service in a sustainable manner. Since then, institutional arrangements have been undergoing significant shifts in Addis Ababa solid waste collection system. With respect to formal sector service delivery, changes have focused on decentralization of solid waste collection service to local government and the introduction of private sector service delivery. At the neighborhood level, community-based initiatives are also becoming increasingly prominent as a means of addressing the deficiencies of the formal system.

The literature on sustainable development of solid waste management distinguishes a large range of possible relationships between the public and private sector, including public-private partnerships, community-public partnerships, and private-private arrangements [2]. Some studies focused on activities within the relationships in the SWM system notably, separation of waste, and the productive use of waste. There are studies that also deal with smallscale business transactions [3] and the impact of official rules and regulations on private or communal undertakings [4]. Effective provision of services to poor households and the safety and health aspects of activities within the SWM sector were areas of concerns given importance by different authors [5]. Baud and Post tried to connect SWM with sustainable development by operationalizing three broad goals: ecological sustainability, socio-economic equality and improvement of health, which are quite similar to our PPP principles [6]. They argue that there is a gap in the current literature on sustainable SWM in developing countries that the system is rarely investigated in its entirety. Assessments combining ecological, environmental health and socio-economic considerations are still largely absent [6]. Moreover, changing institutional arrangements 
among the public sector, the private sector and civil society and their implication as a central theme were not sufficiently addressed.

This research focuses on how households (service users) perceive the service provided by the private sector and local government and their readiness to engage in collaborative efforts to make sure that the system is sustainable. The necessity of exploring users' perspectives to consider sustainable solid waste management arises from three factors:

1. The solid waste collection service by the micro-enterprises at the local government level is greatly influenced by households' attitudes and behaviours,

2. Households are recognized as the main solid waste generators.

3. The institutional relationships in the solid waste management system have been heavily influenced by the introduction of a more participatory approach. The objective of this study is to assess the sustainability of solid waste collection system in terms of being beneficial to the society (profit), the city sanitation (the people) and the environment (planet).

\section{Sustainable Solid Waste Management}

Tadessa showed that households alone generate about $71 \%$ of total waste in Addis Ababa [7]. Solid waste management is an important component of the sustainable development agenda (Agenda 21 in 1992) which is being spearheaded by development partners such as World Bank and the United Nations (UN). During the UN Rio conference a framework on integrated solid waste management was developed, which was eventually transformed into guidelines by Schubeler [8]. Other contributions of solid waste management to socioeconomic, public health and ecologically sustainable development have been made by Sattherthwaite [9].

Sustainability is defined by Van der Klundert and Anschiitz [10] as a system that is: (1) appropriate to the local conditions in which it operates, from a technical, social, economic, financial, institutional, and environmental perspective, and; (2) capable to maintain itself over time without reducing the resources it needs. The problems of solid waste such as inadequate service coverage, irregular waste collection, indiscriminate disposal in unauthorized places, waste spillover from bins and storage containers, and waste littering are common in developing countries [11-13]. These problems eventually lead to public health impact, aesthetic nuisance and environmental pollution.

Van der Klundert and Lardinois [14] highlight the need to review the normal progression of motivations for setting up solid waste management systems. Concerns start with public health and sanitation, develop further to second set of motivations related to quality of life, cleanliness of streets, community appearance, and thirdly again the focus shifts to environmental quality and cost reduction. Finally, the achievement of first-order environmental goals leads to a recognition of the need for sustainable solid waste systems.

The development of 'sustainability indicators', perceived as a first step towards the operationalization of the concept of sustainability, has reflected a pro-active initiative to make a change, itself fired up by a real sense of urgency: "sustainability [becomes] meaningless unless we can do it" [15]. The development of sustainability indicators is now playing an important role in the awakening of new forms of environmental governance [16].

Indicators of sustainability provide a simplified understanding of this concept by providing practical information about the numerous issues encompassed in it. During the past years work was conducted on identifying indicators measuring the level of sustainability reached by solid waste collection systems in selected cities. These normative proxies measures also reflect a trend: they show how far or close we are from being a 'sustainable society' by reflecting the reproducibility of the way a given society utilizes its environment [15].

A major gap in the current literature on SWM in developing countries is that the system is rarely investigated in its entirety, and assessments combining ecological, environmental health and socioeconomic considerations are still largely absent. This study addresses the topic of sustainable solid waste collection, following the municipal service reform in Addis Ababa city by considering new governance elements: decentralization and micro-privatization. The study explores the implication of the reform on the sustainability of the city waste collection system. The following hypothesis is tested 'solid waste service reform improved the sustainability of solid waste collection service in Addis Ababa city'. Sustainability is seen from socioeconomic, public health and ecological perspectives. The study substantiates the issue of sustainability from users' perspective and takes sustainability as caring for the people, the planet and involving the private sector.

\section{Sustainable Solid Waste Collection from a Socio-economic perspective}

Socio-economic sustainability of municipal waste management system depends on many factors: the degree of privatization of waste management services, the extent of public participation, decentralization of responsibilities and tasks related to waste management [16]. Socio-economic sustainability of waste management system indicates its financial viability for households, private enterprises, organizations, and local authorities. The sustainability goal is achieved when the financial costs are balanced with the revenues for all waste managers and consumers paying for the service. The system is not financially viable if one of the partners does not benefit from the existing financial arrangements. From the consumer's point of view "economic affordability" must be taken into account. "Economic affordability" requires that the costs of waste management systems are acceptable to all sectors of the community served (Ibid).

The character of waste management tasks and the technical and organizational nature of appropriate solutions depend a great deal on the economic context of the country and/or city in question and, in fact, on the economic situation in the particular area of a city [17]. Sustainability of a system is achieved when it is able to deliver an appropriate and equitable level of benefits in terms of service quality and affordability over a prolonged period of time without negatively affecting the environment. This implies that the beneficiaries are satisfied with service and the costs are covered through user fees or financial mechanisms [10].

The main effect of micro-privatization has been to improve the existing service. Public service providers are under pressure not so much to reach people whom they are not yet reaching, but to maintain or improve existing services. Micro-privatization achieved both: existing services improved and new clients reached. The services are improved in many different ways; improved the operation, the outreach, the cost effectiveness and the overall quality of the service [18].

Micro-privatization could be a long term and more sustainable solution to the delivery of this public service [2]. Some sort of buyer- 
seller relationship between clients and micro-enterprises enhances commitment and sustainability. Since micro-enterprises operate at a small scale, and are often based in the neighborhood they serve, they favour community participation and control. All solid waste collection systems require some participation by the residents who receive the service. If a community is aware of the refuse collection service, and knows the workers responsible, they are more likely to be ready to pay for the service, than if the service is impersonal and unseen.

\section{Sustainable Solid Waste Collection from an Environmental health Perspective}

The efficient management of urban solid waste in developing countries is vital if environmental cleanliness and public health are not to be compromised. The impact of uncollected waste within cities is enormous. Solid waste accumulation within cities raises public health and environmental concerns because of potential odor from solid waste decomposition and associated insects and rodents. The uncollected solid waste creates conditions favorable for the survival and growth of microbial pathogens. Uncollected solid waste also has aesthetic impact on the environment and also attracts flies, rats, and other creatures that in turn spread disease [19].

Cleanliness should start at household level. The household has the capacity to make its immediate environment healthy and friendly. Household waste is more polluted and miscellaneous, so its collection and sorting costs are quite high. Municipalities face the task of designing schemes for collection of household waste. However, municipal services in developing countries are handicapped by limited finances and an ever-increasing demand on urban services. The failure to provide adequate collection services poses a serious threat to human health and the physical environment [20].

This situation can probably be improved significantly if the inhabitants of low-income communities start assuming the responsibility of handling their own garbage and setting up a system appropriate to their own economic situation. To achieve the objective of sustainability it is necessary to establish systems of solid waste management, which harmonize the technical requirements with the objectives of environmental protection and the needs and interests of different stakeholders especially the urban poor. Many urban poor live in unplanned and unauthorized areas and are, therefore, not eligible for municipal services. Consequently, the solid waste disposal practices of the individual households in un-served high-density areas are mostly detrimental to the living environment of the entire city. To avoid such problems the role played by micro-enterprises is important [18].

\section{Sustainable Solid Waste Collection from Ecological Perspective}

Waste management wants to minimize the material resources that leave the production/trade/consumption cycle in the form of refuse instead of as products that could be reintegrated into economic circulation. Although waste generation rates in developing countries are substantially lower than those in industrialized countries, these rates are not proportionally lower relative to income [21].

Recycling only occurs when the commercial value of the recycled materials covers the cost of extracting them from the waste stream. Modernization pushes - even forces - "a marriage" of services and commodities, with different rules and different cultures, to integrate with, or 'marry', each other. From the solid waste system perspective, the main value of recycling, composting and other commodity-based activities is the reduction in the amount that needs to be moved to a dump, landfill or that is 'lost' and ends up in nature. There is still a big difference between what the principle demands and the social reality in many countries.

Although recycling may be preferred from an environmental perspective, the economic costs involved or the presence of institutional complications may prevent waste recycling from being promoted and implemented in integrated SWM. The actual integration can take place at various levels [22]. These may include waste processors such as formal and informal recyclers, waste generators such as households, industry and agriculture, and government institutions such as waste managers and urban planners.

By working more closely with the communities, micro-enterprises can play a role in public environmental education. Close links with the residents can provide opportunities to introduce separation at source, which would benefit the worker who collects and sells the recyclable materials, and benefit the municipality by reducing the quantity of waste. Community involvement can also improve relationships with service providers, to the benefit of all parties [18].

The pace of development of waste management services heavily depend on the level of public awareness of solid waste-related issues and on participation in making improvements happen at the ground level. The public support for any issue can be greatly increased if the public is fully and well-informed about the reasons behind the actions and the intended benefits [23]. Close links between the microenterprises workers and the residents help to develop such cooperation. Recycling is considered to be an indispensable part of solid waste management and many micro-enterprises are involved in this activity. In Bangkok, formally employed refuse collectors are reported as spending $40 \%$ of their working time recovering recyclables, thereby doubling their wages (Cointreau 1994).

\section{Solid Waste Management in Addis Ababa City}

The city council distinguishes recognizes six major sources of solid waste: households, street, commercial institutes, industries, hotels and hospitals. From total generated solid waste households' account for $71 \%$, street $10 \%$, commercial institutions, $9 \%$, industries $6 \%$, hotels $3 \%$ and hospitals $1 \%$ [24]. Most of the solid waste materials produced by households are disposed without adequate care. A study made by the Addis Ababa City Administration shows that, the collection coverage has been constantly increasing from 38 per cent in 2000 to 40 in 2001, $53 \%$ in $2002,53.9 \%$ in 2004 and $78 \%$ in 2005 [25].

According to Dierig inadequate municipal solid waste collection and disposal creates a range of environmental problems in Addis Ababa [26]. Solid waste management is carried out to protect public health; to promote hygiene; recycle materials; avoid waste; reduce waste quantities, and reduce emissions and residuals. KAPB found that there were different types of diseases caused by improper handling of solid waste in the city [27].

The first level for separation at source in the waste recovery system in Addis Ababa is the household. At this level, materials are considered valuable and are therefore usually sorted out for reuse. The relationships between the different actors, which constitute the recovery system, seem to be based on financial benefit from the sale of their materials rather than on environmental awareness. This is mainly attributed to the fact that the majority of people in Addis Ababa are 
Page 4 of 11

poor. This current state of the recovery system in Addis Ababa is not a perfect example of sustainable recovery of materials [28].

In recent years significant steps have been taken in the appropriate planning of solid waste management to ensure sustainable solid waste management in the city. Partnerships between public, private and community sectors have been established that eventually improved policy statements such as the Waste Strategy developed in 2000 that recognized central principles of sustainable resource management as providing the basis for the development of Addis Ababa Municipal Waste Management. In 2004 the institutional arrangements for the solid waste collection system have been changed. The changes were heavily influenced by decentralization and privatization reforms. Private micro (and small) enterprises are now engaged in collection from households to municipal containers. Simultaneously solid waste collection management has been decentralized to local municipal administration.

\section{Sustainable Solid Waste Collection in Addis Ababa City}

This section covers the analysis of sustainable solid waste collection in Addis Ababa using the perception and attitude of citizens. The analysis takes three perspectives:

(a) a socio-economic perspective: reliability of the service, user charge and affordability of service fee, willingness to pay for better service, and customer support service delivery (b) a public health and sanitation perspective: quality of collection service (household solid waste storage and separation at source) and the existence of a clean urban environment (neighborhood cleanliness, cleanliness of the city) and (c) an ecological sustainability perspective: attitude of society in acceptance of separation at source and household participation in recycling and composting and awareness of a change in values in relation to environmental protection.

\section{Socio-economic Sustainability}

The analysis in this section covers reliability of the service, user charge and affordability of the service fee, willingness to pay for better service, and customer support service delivery (demand and satisfaction for the service). The reliability of waste collection service was assessed in terms of regularity and frequency of waste collection services. Residents were asked whether the service provision by microenterprises to house-to-house collection service was regular.

\begin{tabular}{|l|l|l|l|l|}
\hline \multirow{2}{*}{$\begin{array}{l}\text { Is the collection } \\
\text { service regular }\end{array}$} & \multicolumn{3}{|c|}{ Residential area } & Total \\
\cline { 2 - 5 } & Urban slum & $\begin{array}{l}\text { Residential } \\
\text { area }\end{array}$ & $\begin{array}{l}\text { Commercial } \\
\text { area with } \\
\text { mixed } \\
\text { residence }\end{array}$ & \\
\hline Yes & 92 & 151 & 73 & 316 \\
\hline & $81.40 \%$ & $83.40 \%$ & $68.90 \%$ & $\begin{array}{l}79.00 \\
\%\end{array}$ \\
\hline No & 21 & 30 & 33 & 84 \\
\hline & $18.60 \%$ & $16.60 \%$ & $31.10 \%$ & 21.00 \\
& & & & $\%$ \\
\hline
\end{tabular}

$1 \quad$ It is Ethiopian currency rated 1 birr equivalent to 0.06 USD, September, 2010.

\begin{tabular}{|l|l|l|l|l|}
\hline Total & 113 & 181 & 106 & 400 \\
\hline
\end{tabular}

Table 1: Is the collection service regular in three residential areas?

Table1 presents the residents' response of service reliability of waste collection service. It was evident from the survey that seventy nine (79\%) of the respondents said that the service was regular while twenty one $(21 \%)$ said it was irregular.

Service provision regularity was also looked from the type of settlement perspective (urban slum, residential and residential mixed with commercial areas). Eighty one (81\%) of the respondents in slum area said that the service was regular, whilst $19 \%$ complained about the regularity of the service. In residential area about eighty three (83\%) of respondents said that the service was regular, while $17 \%$ denied the regularity of the service. The service regularity in the residential mixed with commercial area was relatively poor. This suggests that the involvement of micro-enterprises improved access and coverage to slum areas for solid waste collection services in the city.

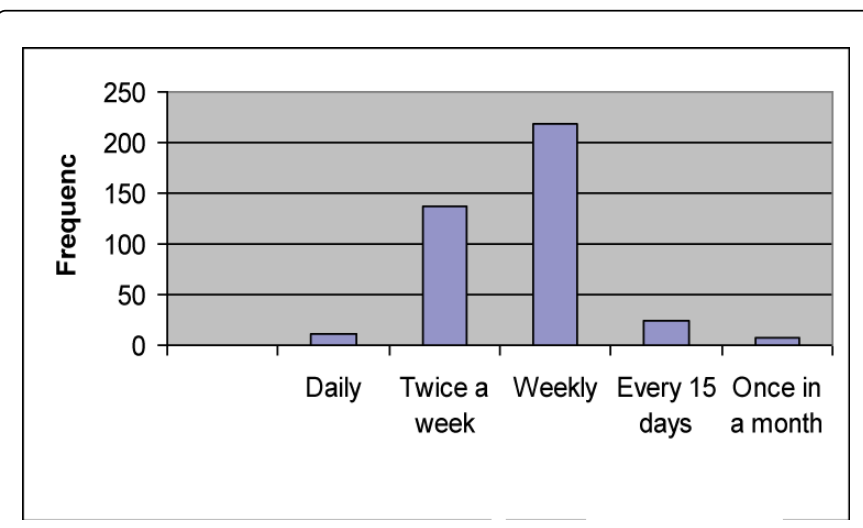

Figure 1: Frequency of waste Collection from Households.

As indicated in Figure 1 the collection frequency of house-to-house collection service rendered by micro-enterprises in Addis Ababa was dominantly once or twice a week. Residents also asked for punctuality of waste collectors in keeping their schedule. The survey results indicate that $67 \%$ of the respondents said micro-enterprises do, while $33 \%$ said they do not keep their punctuality. Some households complained about the promptness of waste collection and argued that a specific date and time is of paramount importance. Micro-enterprises fail to maintain the schedule all the time, while every household has to make sure that the bins are ready. This is a requirement by the local authorities who are responsible to manage the secondary waste collection system in the city. Hence clients started to put waste on their main gates to be picked by the micro-enterprises in their absence. This created further problem as clients complained they do not find back their waste sacks, especially if the sack is new.

Concerning user charges and affordability, the survey revealed that the mean expenditure of city wide current payment for solid waste management service is 10.42 birr. $^{1}$ Solid waste collection service accounts for $30-50 \%$ of the expenses of solid waste management in the developing world cities. $^{2}$ Households were asked about the affordability. As indicated in Table 2 at the city level $62.9 \%$ of the respondents claimed the amount paid was affordable while $23.4 \%$ and 
$13.7 \%$ indicated medium and low level of affordability respectively. Affordability at upper income group is high though there are some variations among middle and low income group.

During the interviews community members mentioned different factors to explain their reluctance of paying the service fee. These include: first the existing procedure of payment for solid waste collection service is based on the amount of water a household consumed. Some households complained about this because they were not clear about the relation between water consumption and waste production; secondly, they use a pit in their compound to prepare compost and sometimes burn it, dispose their waste on municipal skip, and still others argue that they use the waste as fuel to cook food thirdly they are also worried that water meter readers do not come to read the gauge every month. This could have an effect on the amount of money they paid as water payment was calculated based on a progressive consumption pattern.

\begin{tabular}{|c|c|c|c|c|}
\hline \multirow[t]{2}{*}{$\begin{array}{l}\text { Economic status of the } \\
\text { household }\end{array}$} & \multicolumn{3}{|c|}{$\begin{array}{l}\text { Household readiness to pay for } \\
\text { collection fee }\end{array}$} & \multirow[t]{2}{*}{ Total } \\
\hline & Low & Medium & High & \\
\hline \multirow{2}{*}{ Low income } & 18 & 24 & 57 & 99 \\
\hline & $18.20 \%$ & $24.20 \%$ & $57.60 \%$ & $100.00 \%$ \\
\hline \multirow{2}{*}{ Middle income } & 22 & 36 & 99 & 157 \\
\hline & $14.00 \%$ & $22.90 \%$ & $63.10 \%$ & $100.00 \%$ \\
\hline \multirow{2}{*}{ High income } & 12 & 29 & 83 & 124 \\
\hline & $9.70 \%$ & $23.40 \%$ & $66.90 \%$ & $100.00 \%$ \\
\hline \multirow{2}{*}{ Total } & 52 & 89 & 239 & 380 \\
\hline & $13.70 \%$ & $23.40 \%$ & $62.90 \%$ & $100.00 \%$ \\
\hline
\end{tabular}

Table 2: Household affordability to pay for solid waste collection by income.

The affordability can be derived from the payment rate expressing the expenditure for primary solid waste collection as a percentage of the income standard. ${ }^{3}$ For the different households (low, middle and high income) it is $0.8 \%, 0.4 \%$ and $0.25 \%$ respectively. The result is that low income households are paying more for the solid waste collection service than high income households in the city as a percentage of their income.

Finally concerning the willingness to pay Table 3 shows the responses of the households. City wide about half of the respondents $(51.8 \%)$ are willing to pay more for the service improvement, while $48.2 \%$ were not willing to pay. The amount of money respondents were willing to pay towards improved collection service ranges from 2 to 100 Ethiopian birr with mean of 18.46 . Moreover there is clear difference among different economic groups concerning the willingness to pay for improved service; the willingness to pay more is $72 \%, 51 \%$ and $28 \%$ for high, middle and low income households respectively.
The underlying factor that affects peoples' willingness to pay for improved service is the low wages of micro-enterprises workers. The payment to micro-enterprises is based on the volume of waste they collected ( $30 \mathrm{birr} / \mathrm{m} 3$ of waste). Respondents complained that the payments do not serve the mutual interests and benefits of the service provider and service receivers. Moreover households felt that the collected fee was not properly utilized and they consider what they pay is not properly paid to the waste collectors. This notion was substantiated in the community by the idea that workers are working under poor conditions. They are not protected from any exposure of risks and use only elementary equipment.

\begin{tabular}{|l|l|l|l|}
\hline \multirow{2}{*}{$\begin{array}{l}\text { Economic status of the } \\
\text { household }\end{array}$} & \multicolumn{2}{|l|}{$\begin{array}{l}\text { Willingness to pay more for } \\
\text { improved service }\end{array}$} & \multirow{2}{*}{ Total } \\
\cline { 2 - 3 } & Yes & No & \\
\hline \multirow{2}{*}{ Low income } & 28 & 71 & 99 \\
\hline \multirow{2}{*}{ Middle income } & $28.30 \%$ & $71.70 \%$ & $100.00 \%$ \\
\hline \multirow{3}{*}{ High income } & 83 & 79 & 162 \\
\cline { 2 - 4 } & $51.20 \%$ & $48.80 \%$ & $100.00 \%$ \\
\hline \multirow{3}{*}{ Total } & 88 & 35 & 123 \\
\cline { 2 - 4 } & $71.50 \%$ & $28.50 \%$ & $100.00 \%$ \\
\hline
\end{tabular}

Table 3: Willingness to pay more for improved service by household income group.

Some households argue that they have paid additional money to part-time workers as the established system is not effective to manage cleanliness of their surroundings. The responsible persons from the local authority do not monitor what is going on at household level and they focus on dealing with matters related to secondary collection only. The poor sanitary conditions of the slum areas also sparked complaints and induced non-payment from households. Some residents argued that they did not sense any significant change in waste collection in terms of service quality that encouraged them to make additional payment.

Effective demand for waste collection services and customers satisfaction were used to assess whether the service provision was oriented to the customer preference variables. Table 4 shows households' demand for solid waste collection service in Addis Ababa. $60 \%$ of the households joined micro-enterprises as service provider more than three years ago while $40 \%$ less than three years ago. Why they decided to use micro-enterprises as service provider? $42 \%$ of the households said that the demand for waste collection was driven by the community. Informal enterprises in collaboration with households initiated a system, which gave rise to formal micro enterprises. $39 \%$ of the households said they were advised by the local governments (Kebele) to use micro enterprises for primary solid waste collection service. They claimed that the demand for the service was not governed by the interest of an individual household but the households just do what they are told to do by the local government.

2 Collection cost from the total solid waste management accounts 30-50\%. Collection Cost as percentage of income is $0.9-1.7 \%$, $0.5-1.1 \%$, 0.2-0.4\% for Low-income, Middle-income and Industrialized Country respectively (Cointreau, 1994).

3 In this case the cut-off is less than 600 (low income), 600-2000 (middle income) and greater than 2000 birr( high income). 
Page 6 of 11

$10 \%$ of the respondents said as dumping of waste by households to communal containers was banned they adhered to the new procedure that forced them to use micro-enterprises only.

Some households argue that concerning waste collection service by micro-enterprises there was no discussion and communication with the community. Households were not informed about the system and do not own the process. This made them passive. Households complain that they have lost the power to monitor and control the service providers as the government pays and monitors them.

\begin{tabular}{|l|l|l|l|l|}
\hline Period in Service & Frequency & Percent & $\begin{array}{l}\text { Valid } \\
\text { Percent }\end{array}$ & $\begin{array}{l}\text { Cumulative } \\
\text { Percent }\end{array}$ \\
\hline Less than a year & 61 & 14.9 & 15.1 & 15.1 \\
\hline $1-3$ years & 99 & 24.1 & 24.6 & 39.7 \\
\hline $\begin{array}{l}\text { More than three } \\
\text { years }\end{array}$ & 243 & 59.3 & 60.3 & 100 \\
\hline Total & 403 & 98.3 & 100 & \\
\hline
\end{tabular}

Table 4: How long the collection service has been provided to household by the micro-enterprises.

Different views were reflected by the households as to why households preferred the service to be provided by micro-enterprises. Some of the factors raised by the households were: appropriate for the quality of the roads, affordable, involved common people, they were manageable by the community, which is not able to deal with big companies.

\begin{tabular}{|l|l|l|l|}
\hline Satisfaction Level & Frequency & Valid Percent & Cumulative Percent \\
\hline Very satisfied & 29 & 7.4 & 7.4 \\
\hline Reasonably satisfied & 291 & 74 & 81.4 \\
\hline Not satisfied & 64 & 16.3 & 97.7 \\
\hline Don't know & 9 & 2.3 & 100 \\
\hline Total & 393 & 100 & \\
\hline
\end{tabular}

Table 5: Customer Satisfaction Level of primary waste collection Service.

Table 5 shows the rating of the quality of primary solid waste collection service. $74 \%$ of the respondents said that they were reasonably satisfied as the service provision is much simpler, manageable and suited the context. $16 \%$ are not satisfied with the service while $7 \%$ are very satisfied.

Respondents' dissatisfaction was explained by concerns about the interface of primary and secondary collection performed by private micro-enterprises and the public sector, which is not well tuned. The new procedure (contract system) resulted in shifting the problem from the city level to the households. As the respondents explained during the franchise arrangement the waste problem was at city level and this has now become a problem of households since sometimes if the waste is not collected for weeks by micro-enterprises, whenever vehicle and container shortage is encountered, they are instructed to do so by the local government. This aggravated households' dissatisfaction about the collection service. The desired expectation of service quality was not met.

\section{Public Health Sustainability}

The analysis in this section covers the attitude and awareness of households of the quality of collection services. It was found during the study that the majority of households were responsible for household waste storage hygiene. That makes the work for collectors easier. In some cases poor storage conditions were found. Various factors such as non-standardization of household storage materials (their receptacles) and poor warranty to get back their original material from micro-enterprises urged them to use less value materials which subsequently affected the quality. Old worn out material is used by many households. Due to poor storage it is not uncommon to see waste littering around the neighborhoods.

The survey revealed that women are mainly responsible for solid waste management at home-level in the city of Addis Ababa. As indicated on Table 6 in most households these tasks are largely allotted to mothers and maid servants accounting for $41 \%$ and $39 \%$ respectively. They gather the household waste and in some areas push carts are used to deliver it to micro-enterprises.

\begin{tabular}{|l|l|l|l|}
\hline & Frequency & Valid Percent & Cumulative Percent \\
\hline Father & 5 & 1.2 & 4.9 \\
\hline Mother & 168 & 41 & 45.9 \\
\hline Son & 8 & 2 & 47.8 \\
\hline Daughter & 51 & 12.4 & 60.2 \\
\hline Maid & 159 & 38.8 & 99 \\
\hline Guard & 4 & 1 & 100 \\
\hline Total & 410 & 100 & \\
\hline
\end{tabular}

Table 6: Who usually manages and throws out the waste at the household level?

The residents were asked whether there is a waste disposal problem in their neighborhood. The survey revealed that $68 \%$ of the respondents said there is waste littering in their surrounding while $32 \%$ said no. Residents complained about health and safety issues associated with the poor solid waste collection system. Littering was observed during loading of waste on push carts and while transporting. Poor cooperation of residents, poor storage practice of some households resulted in low efficiency of collection and waste remained uncollected on the streets, in open spaces, ditches, roads and rivers and streams. Littering of waste in the neighborhood is common in the city as citizens drop it during the evening illegally. Furthermore it is observed illegal slaughtering and throwing waste in the ditches causes ditches to be clogged and to release an offensive smell. This caused environmental and health hazards, blockage of sewer lines, odour and flies nuisance and aesthetic degradation.

\begin{tabular}{|l|l|l|l|l|}
\hline \multirow{2}{*}{$\begin{array}{l}\text { Type of waste related } \\
\text { neighborhood environmental } \\
\text { problem }\end{array}$} & \multicolumn{4}{|l|}{ Evaluation } \\
\cline { 2 - 6 } & Yes & \multicolumn{2}{|l|}{ No } \\
\cline { 2 - 6 } & Frequency & $\%$ & Frequency & $\%$ \\
\hline Dirty Street & 343 & 86.8 & 52 & 13.2 \\
\hline Rubbish heap & 75 & 19 & 319 & 81 \\
\hline Rubbish in open drain & 339 & 86 & 55 & 14 \\
\hline
\end{tabular}




\begin{tabular}{|l|l|l|l|l|}
\hline Rubbish fire & 26 & 6.6 & 365 & 93.1 \\
\hline Flies and Vermin nuisance & 203 & 51.5 & 191 & 48.5 \\
\hline
\end{tabular}

Table 7: Waste related environmental problems at neighborhoods as rated by the respondents.

Respondents rated waste related environmental problems of the neighborhoods. As shown in Table 7 dirty streets and rubbish in open drains are the major neighborhood waste related problems in the city followed by the nuisance of flies and vermin created by improperly disposed wastes to the surrounding. Households were asked to evaluate their surrounding cleanliness using different items related to the neighborhood waste collection system. Numerical values are assigned to each response in the following manner: $\mathrm{A}=4 ; \mathrm{B}=3 ; \mathrm{C}=2$. Note that the higher the value of the index the cleaner the neighborhood.

\begin{tabular}{|l|l|}
\hline Item & $\begin{array}{l}\text { Numerical value of rated } \\
\text { Mean }\end{array}$ \\
\hline $\begin{array}{l}\text { The household area looks like pleasant residential } \\
\text { area }\end{array}$ & 2.9484 \\
\hline Loose trash are visible in the surrounding area & 2.723 \\
\hline $\begin{array}{l}\text { Waste is neatly collected and transferred to } \\
\text { secondary collection site }\end{array}$ & 3.1642 \\
\hline Neighborhood Cleanliness Index Value & 2.95 \\
\hline
\end{tabular}

Table 8: Neighborhood cleanliness Index of Addis Ababa.

The survey indicates that neighborhood cleanliness index of Addis Ababa was 0.74. During field work it was evident that cleanliness variation among neighborhoods exists. There are developed areas whose cleanliness is $\mathrm{OK}$, but also areas whose conditions were very poor.

Solid waste is dumped at different sites and in drains and other unauthorized places. Households were asked to evaluate the city cleanliness. As indicated in Table 9 the survey reveals that the city cleanliness index of Addis Ababa was 0.6. It was much less than the neighborhood cleanliness index and this is due to lack of public awareness of the health implications of unsanitary practices and residents' indifference to the presence of waste. Individuals put waste in plastic bags and throw it in the narrow streets or under the fence of other households. In some crowded and slum neighborhoods there are no toilet facilities nor at individual nor at the communal level. Hence people are compelled to use plastic bags and/or bowls meant for defecation.

Dust bins are availed in most central parts of the city either as standing on the road or mounted on lamp posts or telegraph poles and strategic sites at points where litter was most likely to be thrown such as bus stops, shopping places and walk streets. However, people do not use dust bins properly, instead they throw bus tickets, soft paper, chewing gums, etc. on the street and are not held responsible for their trash. It was not uncommon to see dust bins used for unintended purpose in the city filled with improper materials like bones and leaves.

\begin{tabular}{|l|l|}
\hline Item & $\begin{array}{l}\text { Numerical value of } \\
\text { rated Mean }\end{array}$ \\
\hline $\begin{array}{l}\text { Loose trash; paper and plastic visible in the city open } \\
\text { areas }\end{array}$ & 2.4532 \\
\hline $\begin{array}{l}\text { Loose trash; paper and plastic visible in the city } \\
\text { street parks }\end{array}$ & 2.6575 \\
\hline $\begin{array}{l}\text { Loose trash; paper and plastic visible in the city } \\
\text { common areas }\end{array}$ & 2.4701 \\
\hline Solid waste is visible in the city water bodies & 2.2125 \\
\hline Solid waste is visible in the city open ditches & 2.2857 \\
\hline Solid waste is visible in the city transfer stations & 2.3401 \\
\hline Street and sidewalks are dusty and dirty & 2.4543 \\
\hline City Cleanliness Index Value & 2.41 \\
\hline
\end{tabular}

Table 9: City Cleanliness Index of Solid waste in Addis Ababa.

Some households argue travelers and migrants are negligent about the cleanliness of the city as they lack ownership and awareness. The responsible body in the city did not fulfill the necessary facilities for them that made them not to adhere to the sanitation rules and regulations in place. In some cases it is observed that many of the public facilities are becoming overburdened due to an increasing population or becoming dysfunctional due to a lack of maintenance. The situation is aggravated by the presence of ownerless dogs that disperse the collected waste at the transfer station while searching for food. It was also observed that the wind disperses the dirt especially thin plastic bags from filled bins, which spoils the cleanliness of the city. Municipal skips from every corner of the city travelled long distance to be dumped on the Repi ${ }^{4}$

Some respondents relate the current situation to the structural problems of the city. Although there are modern settlement areas historically it was common to see houses with different qualities stacked together in the same neighborhood of Addis Ababa. This makes it difficult to develop a shared vision among the residents.

\section{Ecological sustainability}

Ecological sustainability concerns household participation in recycling and composting and the intention to support recycling by practicing in separation at source. Materials in the household waste stream which are capable of being recycled in Addis Ababa city can be

$4 \quad$ The Repi disposal site, nick-named 'Koshé', is the only landfill site to date located $13 \mathrm{~km}$ away from the city centre. This site has been in service since 1968. The site has low area capacity ( $35 \mathrm{ha}$ ) with poor road connection. The present method of disposal is crude open dumping; hauling the waste by truck, spreading and levelling by bulldozer and compacting by compactor bulldozer. It has become full to capacity and the identification of another alternative landfill is already too late. The present situation shows that there are settlements clustered around the site and public health is at risk. The newly constructed Ring Road is too close to it, which makes it a nuisance due to bad smell and pollution in general. The gas generated from landfill causes spontaneous combustion and air pollution in the surrounding area. It contributes enormous amounts of methane and carbon dioxide (green house gas) to the atmosphere. There are more than 800 waste scavengers who permanently browse through the heap of waste looking for recyclable and usable items on the site. 
categorized as dry recyclables, comprising paper, plastics, metals, glass and textile etc. and organic material, consisting of kitchen (food) and garden waste. Both categories of material are recycled in the city, but the method of collection and treatment are quite different. We observed that households dispose certain items in the waste stream in particular non commodity materials (kitchen waste, garden waste, livestock waste). Items that have a intrinsic commodity value (glasses, cans, rubbers, plastics, low grade paper) are locally traded. These materials are bought by itinerant buyers (korale and liwach). The 'Koryalew'5 and 'Liwatch' ${ }^{16}$ are traders who travel from door-to-door and buy/exchange reusable item (tins, plastics, bottles, nail varnish containers, broken cooking jars, used shoes, old garments, etc.) and supply them to the middle men at Mercato.

These traders have a huge impact on the reduction of solid waste both at household and city level. Although they have a well-established economic system and a market niche in the city they were less recognized by the public sector for their contribution to recycling and reuse. There are industries in Addis Ababa that reuse the recovered materials such as paper, glasses, plastic, iron and steel rod and pieces tin, etc. as raw material. Moreover, a large proportion of reusable materials are transported to small towns and rural areas to be used as household items (plastic bottles for storing water, used cans to store materials, reuse of plastic bags etc.).

Table 10 shows that $80 \%$ of the respondents are aware of recycling, while only $13 \%$ exercised recycling. Some households' perception of recycling was from the view point of organic wastes only not aware of reuse and recycling activity from the point of view of material recovery. Most households failed to recognize channeling of materials at household level to small scale collectors serves as precursor for supplying of material input to recycling and reuse process.

\begin{tabular}{|l|l|l|l|l|}
\hline \multirow{2}{*}{} & \multicolumn{3}{|l|}{$\begin{array}{l}\text { HHs have information about } \\
\text { recycling }\end{array}$} & \multicolumn{2}{l|}{ HHs exercising recycling } \\
\cline { 2 - 5 } & Frequency & Valid Percent & Frequency & Valid Percent \\
\hline Yes & 325 & 79.5 & 49 & 13 \\
\hline No & 84 & 20.5 & 329 & 87 \\
\hline
\end{tabular}

Table 10: Households awareness and practice of recycling.

Households reuse/recycle materials for various reasons: economic, environmental concern and both economic and environmental concern. As indicated on Table 11 the survey revealed that $30 \%$ of the households recycle waste purely for economic reasons, $28 \%$ for environmental concerns and $33 \%$ both for economic reason and environmental concern. Interviews with households disclosed that reuse and recycling practice in the city vary with the economic status of the households. There was a growing realization among low income households that household waste should be recycled. The practice of reuse and recycling was attributed to economic and social necessities resulting from poverty and deprivation rather than to environmental considerations.

The positive attitude towards waste re-users and recycling was generally high despite a lack of a formal organized arrangement for source separation and collection of these recyclables. During field study it was observed that refuse collection workers (micro-enterprise workers) rummaged through refuse for valuables. They collected and sold these recyclable and reusable materials for middle men at the secondary collection site. Buying and selling of recyclable materials also takes place at the transfer stations where micro-enterprises bring all recyclable materials from the households and sort them to sell to traders on the spot.

\begin{tabular}{|l|l|l|l|l|l|l|}
\hline & \multicolumn{2}{|l|}{ For economic interest } & \multicolumn{2}{|l|}{$\begin{array}{l}\text { From environmental } \\
\text { concern }\end{array}$} & \multicolumn{2}{l}{$\begin{array}{l}\text { For both economic } \\
\text { and environmental } \\
\text { concern }\end{array}$} \\
\cline { 2 - 7 } & Frequency & $\begin{array}{l}\text { Valid } \\
\text { Percent }\end{array}$ & $\begin{array}{l}\text { Frequenc } \\
\text { y }\end{array}$ & $\begin{array}{l}\text { Valid } \\
\text { Percent }\end{array}$ & Frequency & $\begin{array}{l}\text { Valid } \\
\text { Percent }\end{array}$ \\
\hline Yes & 121 & 30 & 111 & 27.6 & 133 & 33.1 \\
\hline No & 283 & 70 & 291 & 72.4 & 269 & 66.9 \\
\hline
\end{tabular}

Table 11: Households perspectives of recycling in Addis Ababa.

Organic waste accounts for $70 \%$ of the total. The daily generated solid waste is more than $2000 \mathrm{~m}^{3}$ whereas the annual generated waste amounts to be around $1,000,000 \mathrm{~m}^{3}$. Despite the huge potential currently only $6 \%$ of the solid waste reported used for making compost [27]. Most respondents claimed this to be due to a lack of space to practice gardening. Some said they do not have a market if they produce compost. While others said that they have heard about composting but they did not see anything done so far that would encourage households to participate. Some complained that they neither got support from a concerned body nor have capacity and knowledge to compost.

According to the Refuse Collection and Disposal bye-laws of Addis Ababa city, 2001 Section 4 (1 and 2) and Section 5, all households are required to have two solid waste collection receptacles (one for organic and the other for non-organic waste) of not less than 40 litres fitted with a lid. The two types of waste receptacles are meant to facilitate sorting of waste at the source. It has been noted during the survey that this bye-law has not been adhered to.

$90 \%$ of the respondents do not practice separation at source. Table 12 shows that $47 \%$ of the respondents don't have awareness about waste separation. $23 \%$ argue that there is no point of separating waste since as collectors they use only one bag per household. $12 \%$ believed that they have no reason to do it as they lack the facility. More education should create the awareness about separation at source.

\begin{tabular}{|l|l|l|l|}
\hline & Frequency & $\begin{array}{l}\text { Valid } \\
\text { Percent }\end{array}$ & Cumulative Percent \\
\hline It is small & 42 & 10.2 & 20.7 \\
\hline No facility & 47 & 11.5 & 32.2 \\
\hline No awareness & 183 & 44.6 & 76.8 \\
\hline No incentive & 95 & 23.2 & 100 \\
\hline Total & 410 & 100 & \\
\hline
\end{tabular}

Table 12: Why there is no source separation at Household Level.

\footnotetext{
$5 \quad$ 'Koryalew' is an abbreviation for Korkoro-yalew meaning him or her who has tin-made discarded materials for sale.

6 'Liwatch' means old used materials to be swapped with other usable items and includes old clothes, shoes ... etc and in return to take new plates, plastic-made cups, kettles, small containers ... etc.
} 
However there is an effort made by individuals at household level to separate waste for different purposes. There are households that have been trained by government, civil society and community based organization to separate the organic part of the waste and use compost in their compound. Low income households separate waste and use it for different purposes (like energy). Some households separate some types of waste (broken glass, ash) at their own initiative just to ease the task of micro-enterprises as some waste types are difficult to handle with other wastes together.

To understand values and behaviour of residents concerning solid waste management, a factor analysis was done. Table 13 simplified the data by grouping them under two common factors. ${ }^{7}$ Factor 1 was designated as 1st and 2nd motivation which include health, sanitation, aesthetic, cleanliness of streets and open areas and city image, since it was generally opted for by certain categories of respondents. Factor 2 was named as 3 rd motivation which covered natural resource depletion and trans-boundary effects caused by improper management of solid waste. It became evident that there were certain differences in the perception of these two groups (table 13 and figure 2).

\begin{tabular}{|c|c|c|}
\hline & Component & \\
\cline { 2 - 3 } & $\mathbf{1}$ & $\mathbf{2}$ \\
\hline $\begin{array}{c}\text { Personal health as most urgent problem related with } \\
\text { AA solid waste }\end{array}$ & 0.552 & -0.3 \\
\hline $\begin{array}{c}\text { Risk of epidemic as most urgent problem related with } \\
\text { AA solid waste }\end{array}$ & 0.649 & -0.336 \\
\hline $\begin{array}{c}\text { Littering of environment and inconvenience due to } \\
\text { odour }\end{array}$ & 0.628 & -0.067 \\
\hline Reduce aesthetic of the city & 0.759 & -0.076 \\
\hline Affect cleanliness of the city streets and open areas & 0.676 & -0.07 \\
\hline $\begin{array}{c}\text { Causes air pollution } \\
\text { Causes surface and underground water pollution }\end{array}$ & 0.641 & 0.13 \\
\hline Causes natural resource depletion & 0.643 & 0.104 \\
\hline Affect the sustainability of local and regional \\
environment
\end{tabular}

Table 13: Rotated Component Matrix. Extraction Method: Principal Component Analysis. Two components extracted.

The results implied that residents' perception of solid waste problem at the city level was in the transition between first and second order motivation. People are more concerned about second motivation; aesthetic, cleanliness of streets and city image. Indeed the concern given by the residents for first order motivation; health and sanitation was also considerable.

Figure 2 indicates that solid waste minimization as a strategy to reduce natural resource depletion and its impact in lessening local and regional environmental effects are valued differently by the community. Waste minimization/reduction as a principle was experienced less as the knowledge and support to the system was nonexistent at household level in the city.

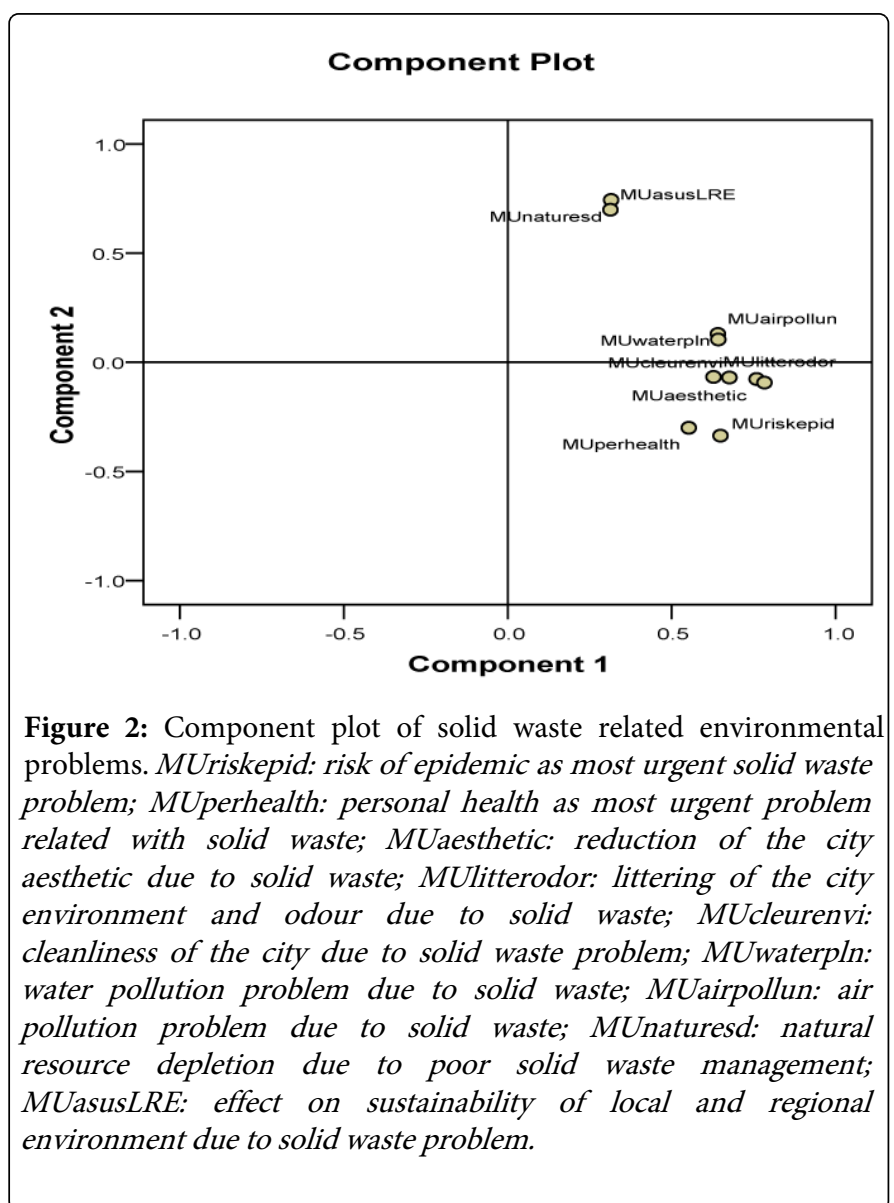

\section{Discussion}

The institutional relationships in the solid waste management system have been undergoing significant shifts in Addis Ababa, influenced by decentralization and micro-privatization policies creating an alternative service delivery mechanism to improve municipal solid waste management. Local government, community and private sector are now more involved. This collaboration ensures that each and every move fits into an integrated and sustainable system designed for promoting service satisfaction, public health, environmental protection, and good governance.

Despite private sector involvement in solid waste management in developing countries in the past two decades, there are still problems with solid waste management services [12]. The micro-privatization process in Addis Ababa waste collection strategies using groups of entrepreneurs seems quite effective in maintaining the sustainability of the system from various perspectives: economic status of the residents, the nature and type of waste generated in the city, the capacity of local governments to administer the privatization process, availability of resources and technologies to the public sector should be mentioned. Micro-enterprises operating in a low-income neighborhood have a definite advantage because trucks are unsuited to the hilly, unpaved or

\footnotetext{
7 The factor solution was derived from the component analysis with VARIMAX rotation of the 10 environmental problems related with solid waste listed for the purpose of the study. Factor 1 has 8 significant loading while 2 problems listed significantly under factor 2.
} 
narrow streets that are common in the majority of settlement areas. Moreover micro-enterprises are location specific, they are responsible to the area where they function, and keep the cleanliness of the surrounding.

Decentralization of the service to the Kebele level makes it much more manageable and helps to increase efficiency as the Kebele is the smallest unit of the Mass Organizations. It is therefore evident that SWM in Addis Ababa has improved the sustainable provision of solid waste collection service as the reform measures included user financing, proper organization of the responsible bodies, encouraging and promoting of efforts of the other stakeholders that are helpful in alleviating the problems, promoting the SWM Office to become an autonomous player. The Kebeles are acting as bridge connecting the community with the Municipality. Moreover they organize and coordinate the activities of micro-enterprises and community-based organizations (CBOs) pertaining to SWM.

The newly formed institutional arrangements require a different approach to governance to mainstream sustainable solid waste collection. More research is required on institutionalization of the reform (decentralization of service delivery to local authorities and micro-privatization of the service) to ensure the sustainability and appropriateness of the system as an alternative service delivery mechanism. Further research would be necessary to evaluate sustainability from the providers' and regulators' perspectives as this study is limited to users' perspective only.

\section{Conclusions}

The study evaluated households' attitude and behaviour concerning sustainable solid waste collection. Sustainability has been considered from the socio-economic, public health and ecological, or the three Ps perspective. Various indicators and the underlying factors were considered under socio-economic, public health and ecological sustainability principles. The research tried to explore the indicators and the underlying factors influencing the sustainability of solid waste collection service provision scheme from the users' perspective.

The study uncovered several important factors that are associated with sustainable solid waste collection. In the case of socio-economic sustainability: reliability, affordability, service coverage, customer support services and willingness to pay for improved service are the variables considered. The results of this study suggest that the service reform suited the interests of the city community in undertaking the service provision function in a sustainable manner. Regularity, reliability, service coverage and frequency of service delivery to the households have improved. Residents have a good feeling about cost recovery, as micro-enterprises require less money and are more cost effective even though there is variation of attitude on cost recovery among different economic groups.

With regard to public health sustainability improvements were observed concerning the cleanliness of the neighborhoods as compared with the city cleanliness. Households are sympathetic to neighborhood level sanitation. The sanitation level of neighborhoods has apparently improved implying that micro-enterprises are taking their responsibility progressively. However, city sanitation suffers largely from the public-private interface in the system. The dreadful attitude and lack of co-operation of inhabitants at the city level account for the irresponsible littering behaviour of transitory people explained by the problem of migration, travelers and traders, the city structure, ownership issues, illegal functions in the city, awareness, prisoners' dilemma, and local versus city sanitation discourses (procedurally, administratively, and perception wise). Poor monitoring capacity of local administration is also the potential contributor to the problem.

In the case of ecological sustainability even if the awareness level of residents for separation at source is low, economic incentives play a more important role than ecological considerations in separating and channeling reusable and recyclable items from the waste stream at household level. Reuse and recycling of waste in Addis Ababa is mainly undertaken by micro-enterprises. Massive market transactions of recyclable materials take place at the transfer stations, where microenterprises bring all recyclable materials from the households and sort them to sell them on the spot. Though there is no legitimate strategy and regulations of methods of collection to be employed, microenterprises act informally and offer stable supplies of material for reprocessing. However, the markets for some types of recycled materials are not considered sufficiently, since without this market the recycling loop cannot be closed. The reuse and recycle practice of waste at household level is too low. Only low income households exercise recycling activities because of economic reasons. Waste minimization as a principle is not really adhered to as there is no knowledge of and support for such a system at the household level. These results have implications for further studies. More research is required to consider sustainability not only from the collection perspective but also by looking at solid waste management as a system.

\section{References}

1. Sibley J, Hes D, Martin F (2003) A triple helix approach: An inter disciplinary approach to research in to sustainability in outer-suburban housing estates. Methodologies in housing research. Stockholm.

2. Tilaye M, van Dijk MP (2014) Private sector participation in solid waste collection in Addis Ababa (Ethiopia) by involving micro-enterprises. Waste Manag Res 32: 79-87.

3. Van Dijk MP, Tilaye M (2013) Micro-privatization of solid waste collection service, the case of Addis Ababa city. In Water lines 32: 154-162.

4. Oduro-Kwarteng S, van Dijk MP (2013) The effect of increased private sector involvement in solid waste collection in five cities in Ghana. In: Waste management \& research 31: 81-93.

5. Huysman M (1994) The Position of Waste Pickers in Solid Waste Management in Bangalore. Rotterdam: IHS of Erasmus university.

6. Baud I, Post J (2002) Between market and partnership: Urban solid waste management and contribution to sustainable development. GBER 3: 46-65.

7. Tadesse K (2004) Dry Waste Management in Addis Ababa City. Accounting for Urban Environment. Ethiopian Development Research Institute, Addis Ababa, Ethiopia.

8. Schubeler (1996) Conceptual Framework for Municipal Solid Waste Management in Low Income Countries.

9. Sattherthwaite D (1997) Sustainable Cities or Cities that Contribute to Sustainable Development? Urban Studies 34: 1667-1691.

10. Van der Klundert A, Anschiitz J (2000) The Sustainability Of Alliances Between Stakeholders In Waste Management.

11. Zurbrugg C (1999) Solid Waste Management in Developing Countries.

12. Onibokun AG, Kumuyi AJ (1999) Governance and Waste Management in Africa.

13. Oduro-Kwarteng S (2011) Private Sector Involvement in Urban Solid Waste Collection: Private Sector Performance, Capacity and Regulation in five Cities in Ghana. Rotterdam: Erasmus University. 
Citation: $\quad$ Tilay M and van Dijk MP (2014) Sustainable Solid Waste Collection in Addis Ababa: the Users' Perspective . Int J Waste Resources 4: 158. doi:10.4172/2252-5211.1000158

Page 11 of 11

14. Van der Klundert A, Lardinois I (1995) Community and Private (formal and informal) Sector involvement in Municipal Solid Waste Management in Developing Countries. Waste.

15. Bell S, Morse S (1999) Sustainability Indicators. Measuring the immeasurable. Earthscan, London.

16. Simon S (2003) Sustainability Indicators. International Society for Ecological Economics.

17. Žickiene S (2005) Municipal Solid Waste Management: Data Analysis and Management Options: Environmental research, engineering and management 3: 47-54.

18. Harper M (2000) Public Services Through Private Enterprise: Microprivatisation for improved delivery London UK.

19. Sheinberg A (2003) Privatization and the Informal Sector: Thinking locally, acting globally?

20. You N, Allen A (2011) Sustainable Urbanization: Bridging the Green and Brown Agendas, University College London.

21. Tchobanoglous G (1993) Integrated solid waste management: Engineering principles and management issues McGraw-Hill, New York.
22. Lardinois I, Van der Klundert A (1997) Integrated Sustainable Waste Management.

23. Wilson E, McDougall FR, Willmore J (2001) Euro-trash searching Europe for a more sustainable approach to waste management. Resources Conservation and Recycling 31: 327-346.

24. Cointreau-Levine S (1994) Private Sector Participation in Municipal Solid Waste Services in Developing Countries.

25. Addis Ababa Sanitation, Beautification and Parks Development Agency (AASBPDA) (2005) Guideline for Delimiting Service Areas for Micro and Small Enterprises Engaged in Solid Waste Collection and Transportation. Addis Ababa (Amharic Version).

26. Dierig S (1999) Urban Environmental Management in Addis Ababa: Problems Policies Perspectives and the Role of NGOs.

27. Knowledge, Attitude, Perception and Behaviour (KAPB) (2009) Survey of Addis Ababa Sanitation. Addis Ababa.

28. Baudouin A (2009) Waste Management and Governance in Addis Ababa. 